\title{
ヒト間葉系幹細胞の骨芽細胞分化誘導時における 遺伝子発現の変化
}

\author{
渡 邊 希 江 \\ 東京医科歯科大学大学院医㐘学総合研究科口腔機能再構築学系 \\ 摄食機能保存学講座 搯食機能保存学分野 \\ (主任・指導：三浦宏之教授)
}

（2003 年 12 月 8 日 受付）

\begin{abstract}
Assessment of Gene Expression during Osteoblast Induction of Human Mesenchymal Stem Cells
\end{abstract}

WATANABE Kie

Fixed Prosthodontics, Department of Restorative Sciences, Division of Oral Health Sciences, Graduate School,

Tokyo Medical and Dental University

(Chief and Director: Prof. Miura Hiroyuki)

\begin{abstract}
The aim of this study was to define transcriptional changes that occur during dexamethasone-induced in vitro osteoblastic differentiation using human mesenchymal stem cells (hMSCs). Bone marrow derived hMSCs from three individual donors were grown in DMEM containing 10\% fetal bovine serum and antibiotics (basal media, BM). At confluence (Day 0), cells were grown in BM or BM plus ascorbic acid, $\beta$-glycerophosphate and dexamethasone (OS). At 0, 3, 7 and 14 days, total RNA was isolated from hMSCs, and ${ }^{32} \mathrm{P}$-labelled probes were synthesized. Atlas 1.2 gene arrays (Clontech) were hybridized with donorspecific cDNA probes. Acquired data were analyzed using GeneSpring Software（Silicon Genetics）enabling normalization and averaging of donor-specific data sets at each time point. Only 8, 31, and 27 genes were upregulated more than 3-fold at 3, 7 and 14 days, respectively. Over 50 genes were downregulated at each time point. Interestingly, the results of this study did not reflect commonly identified genes that are frequently considered in cellular differentiation along the osteoblastic lineage. Instead, some interesting genes were upregulated. Seven days exposure to OS media resulted in the relatively high induction of several genes, including growth factors and receptors which affect adipocyte, chondrocyte and osteoblast differentiation. IGF II and FGFR 3, FGFR 2 were upregulated in the middle of 14 days' induction. Examination of gene expression at day 14 also revealed a number of receptors (LEPR) and transcription factors (ROR $\alpha$ ) were upregulated during 14 days. These could be of importance to the process of early stage differentiation.
\end{abstract}

\section{I 。緒言}

近年，多様な分化能をもつとされる幹細胞の再生医療 への応用が大いに期待されている。なかでも成人骨髄か ら抽出できる間葉系幹細胞については, 骨細胞・軟骨細 胞・筋細胞・脂肪細胞などに分化しうる自己の細胞とし て，その利用に対する期待は大きく，盛んに研究が行わ れている。とりわけ細胞の分化決定機序の解明は, 幹細 胞を用いた再生医療の実現には必要不可欠であることか
ら，分化過程で惹起される遺伝子発現の変動に関して， 末分化間葉系幹細胞の遺伝子発現パターン解析 ${ }^{1)}$, 軟骨 への分化過程 ${ }^{2}$, そして骨芽細胞への分化過程 ${ }^{3)}$ での遺伝 子発現パターンの解析など多くの研究がなされている。

分化した骨芽細胞に特異的な遺伝子発現についてはあ る程度解明されているが，末分化間葉系幹細胞からの骨 芽細胞への分化過程における遺伝子発現の変化について はいまだ不明な点が多く，七ト間葉系幹細胞 (hMSC) の 骨芽細胞への分化誘導時に惹起される変化を解明するこ 
とは，骨芽細胞分化の機序を理解するための一つの有効 なアプローチといえる。

本研究では, これら分化過程における遺伝子発現の変 化を検索するために, hMSCを骨芽細胞に誘導し, cDNA アレイによる比較を行った。hMSC は 3 名のド ナーの骨髄から抽出されたものを用い，1,176 個の遺伝 子発現の変化を比較検討した結果, 興味深い遺伝子発現 の変化が明らかになったので報告する。

\section{II. 方 法}

\section{1. 細胞培養}

hMSC は，米国 IRB の規定に基づいてインフォーム ドコンセントのもと 3 名のドナー腸骨骨髄より抽出し た。hMSC の抽出方法, 培養条件については Haynesworth らの方法に従った ${ }^{4)}$ 。抽出後の hMSC 培養には $10 \%$ ウ シ胎児血清(FBS)，ペニシリンストレプトマイシンを添 加した Dulbecco's modified Eagle's medium (DMEM, $\mathrm{BM})$ を用い， $37^{\circ} \mathrm{C}, 5 \% \mathrm{CO}_{2}$ 条件下にて培養した。コン フルエントになった時点（Day 0) で, Osteogenic supplemented 培地 (BM $に 0.1 \mu \mathrm{mol} / l$ dexamethasone (Dex), $0.05 \mathrm{mmol} / l$ ascorbic acid(ASA), $10 \mathrm{mmol} / l$ $\beta$-glycerophosphate $(\beta-\mathrm{GP})$ を添加したもの ${ }^{5)}$ での培養 を開始し，骨芽細胞分化を誘導した。OS 培地は毎日交換 し，OS培地に切り替えてから 14 日目まで培養を続け た。

\section{RNA 抽出}

骨芽細胞分化誘導開始時 (0 日目), 誘導後 $3 ， 7 ， 14$ 日 目の細胞から, Nucleospin Nucleic Acid Purification Kit（クロンテック社）を用いて全 RNAを抽出し, DNase 処理によって GenomicDNA を除去した。

\section{3. 骨芽細胞分化過程の检証}

hMSC 12 well の細胞培養プレート上に播種し, OS 培地のもと骨芽細胞への分化をモニターする目的で, 0〜14 日までのアルカリフォスファターゼ活性を Sigma Diagnostics Alkaline Phosphatase kit \# 85 (Sigma 社) により，また骨芽細胞マーカーとして知られるコラーゲ ン type I (COL I ), オステオカルシン $(\mathrm{OC})$ さらに骨 シアロプロテイン (BSP)については mRNA 発現レベル をRT-PCR 法により検証した。RT-PCR の際の cDNA 合成には SuperScript II (Invitrogen 社) を用い, Cooper $ら^{6)}$ の方法に従って反応を行った。これらの骨芽細胞 マーカーのcDNA は, 本研究で用いたcDNA アレイ上 には含まれていなかった。

4. プローブ合成と cDNA アレイハイブリダイゼーション 抽出したRNA から, Atlas Pure Total RNA Labeling Kit（クロンテック社）を用いて poly + A RNA を精 製, $\left[{ }^{32} \mathrm{P}\right] \mathrm{dATP}$ で放射線標識して, ドナーごとにそれ
ぞれのタイムポイントでプローブを作成した。使用し たcDNAはクロンテック社Atlas Human Array 1.2 (1,176 genes)で, 八イブリダイゼーションに は，各サンプルともにおよそ $8.0 \times 10^{6} \mathrm{cpm}$ ずつを用い た。

\section{CDNA アレイデータ解析}

反応後の cDNA アレはフォスフォイメージャー Storm 840 (Molecular Dynamics) を用いてスキャンし て, 取り込んだ画像はデジタル化した。Atlas cDNA ア レイ専用の解析ソフトウェア Atlas Image 2.0 software (クロンテック社)を用いて，アレイ上のスポットごとの シグナル強度を数值化し，標準化を行った。おのおのの ドナーごとに，0日目のプローブにハイブリダイズした アレイと $3,7,14$ 日目のプローブにハイブリダイズした ものとを比較し，遺伝子ごとの発現強度をDay 0 の同じ 遺伝子のシグナル強度に対する比として算出し（ratio= Day 3 またはDay 7 また Day 14 のシグナル強度/ Day 0 のシグナル強度), 遺伝子発現強度の相対的変化を 示した。

ドナーの特異性を排除する目的で, ドナー別に算出さ れた ratio を GeneSpring Software 4.2.1 (Silicon Genetics 社）を用いてタイムポイントごとに平均化し, さらに 3 fold 以上のものを変化があったとみなした。

\section{6. クラスター解析}

平均化したデータに対し, mRNA 発現の変動の傾向 を解析するため, GeneSpring Software 4.2.1を用いて K-means クラスタリング解析を行い，14 日間の骨芽細 胞誘導期間における mRNA 発現レベルの変動パターン 別に 7 つのセットに分類した。

\section{RT-PCRによる確認}

OS 培地下で培養後 $0 ， 3 ， 7 ， 14$ 日に得られた RNA か ら, Superscript IIを用いて cDNA を合成した。興味深 い発現の変化がみられた Insulin-like growth factor II (IGF II), Leptin receptor(LEPR), Fibroblast growth factor receptor 3 (FGFR 3), Retinoic acid receptorrelated orphan receptor $\operatorname{ROR} \alpha(\operatorname{ROR} \alpha)$ について, そ の mRNA 発現強度の変化を確認するため, 表 1 に示す 条件で Taq polymerase (Invitrogen 社) を用いて PCR を行った。

\section{III. 結果}

\section{1. 骨芽細胞分化への誘導}

アルカリフォスファターゼ活性は 14 日間の培養の過 程で上昇していることが確認され, 骨芽細胞分化マー カー (COL I, OC, BSP) の mRNA 発現レベルの上昇 も認められた（図 1，2）。 
表 1 RT-PCR 法で用いたプライマーおよび条件

\begin{tabular}{|c|c|c|c|}
\hline $\begin{array}{l}\text { Target } \\
\text { mRNA }\end{array}$ & Location & Sequence & $\begin{array}{l}\text { Annealing } \\
\text { Temperature }\end{array}$ \\
\hline \multirow[t]{2}{*}{ IGF II } & Upstream & 5'-TGCATTGCTGCTTACC-3' & 56 \\
\hline & Downstream & 5'-GTCCCTCTCGGACTTG-3' & \\
\hline $\mathrm{LEPR}^{22)}$ & $\begin{array}{l}\text { Upstream } \\
\text { Downstream }\end{array}$ & $\begin{array}{l}\text { 5'-TGTTGTGAATGTCTTGTGCC-3', } \\
\text { 5'-TACTCCAGTCACTCCAGATTCC-3, }\end{array}$ & 55 \\
\hline \multirow[t]{2}{*}{ FGFR $3^{23)}$} & Upstream & 5'-GCCGAGGAGGAGCTGGTGGAGGCT-3' & 60 \\
\hline & Downstream & 5'-CTTGAGCGGGAAGCGGGAGATCTTG-3' & \\
\hline $\mathrm{ROR} \alpha^{21)}$ & $\begin{array}{l}\text { Upstream } \\
\text { Downstream }\end{array}$ & $\begin{array}{l}\text { 5'-GTAGAAACCGCTGCCAACA-3' } \\
\text { 5'-ATCACCTCCCGCTGCTT-3' }\end{array}$ & 56 \\
\hline
\end{tabular}

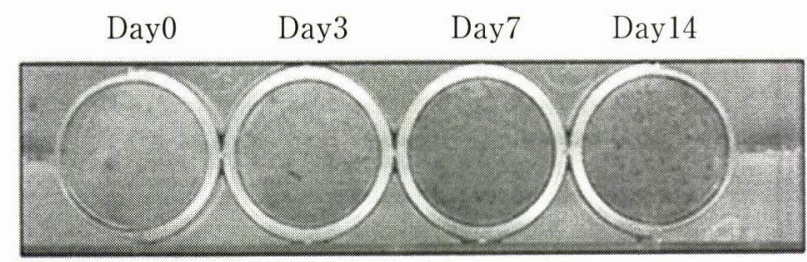

図 1

12 well 培養ディッシュ上でhMSC を培養, 骨芽細胞に誘 導し, 誘導後 $0 ， 3 ， 7 ， 14$ 日目にALP 活性染色したものを示 す。14 日目に向かって ALP 活性が上昇している。

\section{2. cDNA アレイによる遺伝子発現分析の結果について}

cDNA アレイによる解析の結果, 分化誘導後 3, 7, 14 日目において，それぞれ8，31，27個の遺伝子発現レべ ルの上昇 (ratio $\geqq 3$ fold) がみられ，発現レベルが減少し た遺伝子 (ratio $\leqq 0.3$ fold) は，それぞれ 57，52，107 個 であった。 K-meansクラスター分析により，類似した発 現変動パターンを示す遺伝子を 7 つクラスに分類した ものを, 図 3 に示す。

骨芽細胞分化誘導後 3 日目で ratio が最も大きかった のは Insulin-like growth factor II (IGF II) の 5.3 fold で, IL-4 receptor は 4.4 fold, Integrin alpha 5 は 3.8 foldであった。 3 日目にのみ発現上昇がみられたものは， Transcription factor GATA-4 などで, クラスターセッ ト 1 に分類した。

7 日目では，すべてのタイムポイントのうち最も多く の遺伝子の mRNA 発現レベルが上昇した。Fibroblast growth factor receptor 3 (FGFR 3, 12.5 fold), Fibroblast growth factor receptor（FGFR 2, 8.7 fold）など の成長因子, Activin type I receptor ( 4.4 fold), Leptin receptor (LEPR, 5.2 fold) などの細胞レセプターの上 昇が認められた。これらはクラスターセット 5,6 に分類 し，このセットには細胞レセプターや転写因子が多く含 まれていた。

14 日目で発現が上昇したものはクラスターセット7

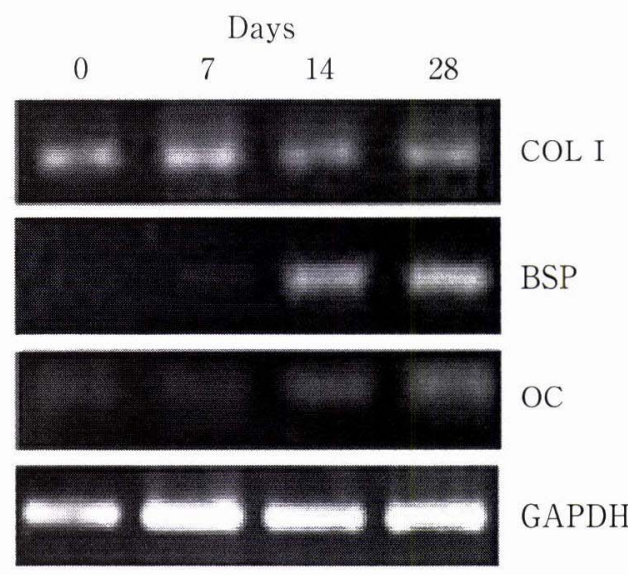

図 2

骨芽細胞分化マーカーの mRNA 発現レベルの変動を示 す。骨芽細胞分化誘導後 0 日目から 28 日目まで培養した hMSC から全RNA を抽出, Col I, BSP, OCそして GAPDH について RT-PCR 法を用いてその発現を確認し た。

に分類 $L$, Retinoic acid receptor-related orphan receptor $\operatorname{ROR} \alpha(\mathrm{ROR} \alpha, 5.6$ fold $)$, Transcription factor Sp 1 (4.1 fold), Helix-loop-helix protein (3.7 fold) などの転写因子と Casein kinase I gamma (3.7 fold) などの細胞内キナーゼネットワーク因子が多く含まれて いた。

14 日間を通して持続的に発現上昇がみられたものは クラスターセット 4,5 に分類 L, IGF II, LEPRや Fibronectin receptor alpha subunit が含まれていた。

K-means クラスタリング解析により,クラスターセッ ト 4， 5，6，7 から 1 つずつの興味深い遺伝子, 計 4 つに ついて, RT-PCR 法を用いてその発現量の変化を確認し た。その結果，4つの遺伝子(IGF II, LEPR, FGFR 3, $\mathrm{ROR} \alpha)$ の $\mathrm{mNA}$ 発現レベルは, cDNA アレイの結果 にほぼ対応して上昇していた。（図 4)。 
Cluster Days

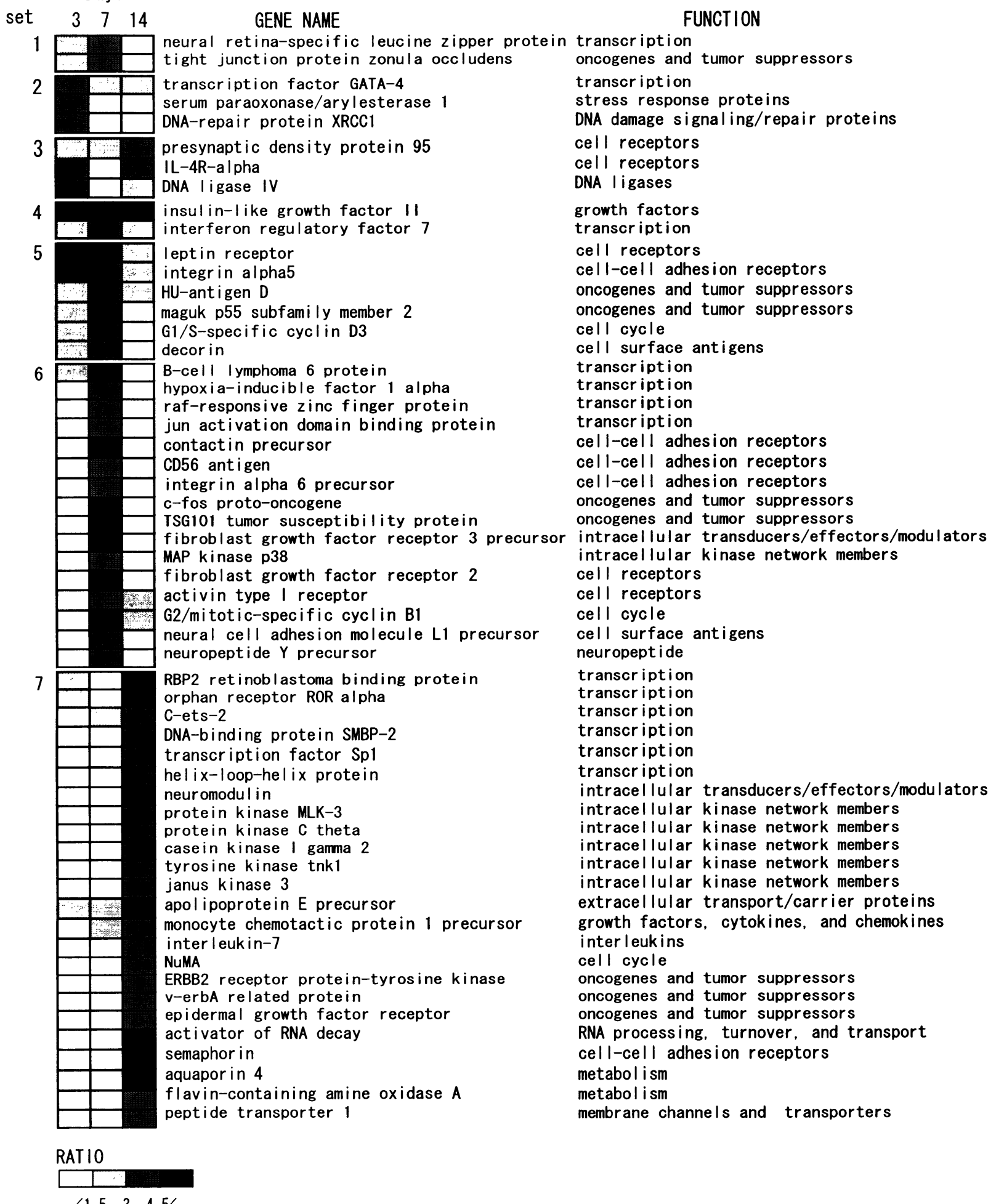

発現パターンの類似している遺伝子を K-means クラスタリングにより７つのセットに分類し，いずれかのタイム ポイントで 3 fold 以上発現が増加しているものをクラスターセットごとに示す。Ratio の大きさにより色の濃淡で表 した。 


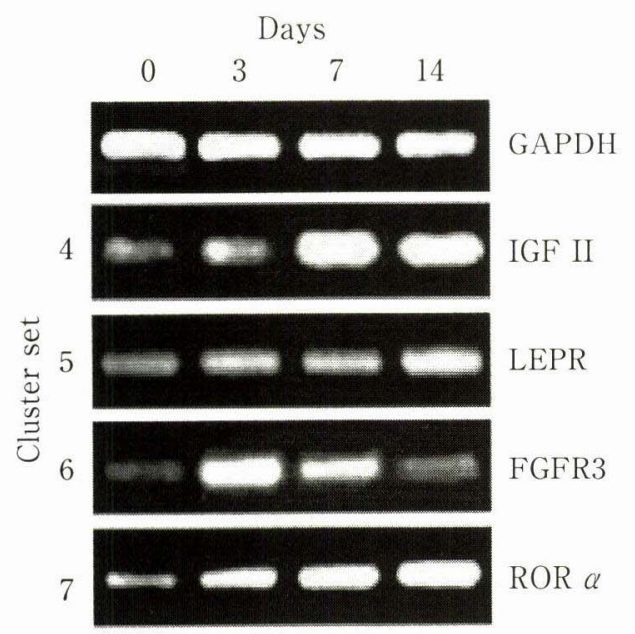

図 4

クラスターセット 4, 5，6，7 より選出した IGF II，LEPR, FGFR 3, ROR $\alpha$ にいて, RT-PCR 法による mRNA 発現 レベルの変動を示す。アレイに用いたものと同じ RNA から cDNAを合成，それぞれ表1に示すプライマーと条件で PCR を行った。

\section{IV。考察}

図 1，2 より，14 日間の分化誘導で ALP，骨芽細胞分 化マーカーの mRNA レベルが上昇していることが認め られ, 本実験の培養条件において hMSC の骨芽細胞への 分化が誘導されていることが確認された。

本実験の結果では，一般的によく知られる骨芽細胞特 異的遺伝子拈よび TGF $\beta$ スーパーファミリーの発現上 昇は認められなかった。使用したcDNAアレイには, BMP-1，2，3，4，5，6，8 が含まれていたが，いずれも 発現量は少なく, 発現レベルの変動もみられなかった。 BMPs は未分化な間葉系幹細胞を骨芽細胞, 軟骨細胞, 脂肪細胞へ分化させ，さらに，未分化な骨芽細胞（前骨 芽細胞）に作用寸ると，それらを成熟した骨芽細胞へと 分化させる。細胞から分泌された BMP は, 産生細胞また は周囲の細胞の BMP レセプターに結合することにより その作用が発現する。またDiefenderfer ら゙により， hMSC に扔けるBMPシグナリングを活性化する経路 は, 一つではない可能性が示唆されている。本実験で, 分化途中の hMSC では BMP の発現が上昇しなかった。 すなわち，骨芽細胞の分化過程の少なくとも初期から中 期においては，BMPや TGF $\beta$ スーパーファミリーが オートクラインに作用する機序は必須ではないというこ とである。

しかし，一方で骨形成の過程で重要な役割を示すいく つかの興味深い遺伝子の発現変動が認められた。

IGF II はすべてのドナーで強く発現が上昇しており, 3 日目で ratio が 5.31 fold, 7 日目 6.21 fold， 14 日目
4.59 fold であった。IGFs は, 骨量を決定するのに重要な 役割を担っており ${ }^{8)}$ ，特に IGF II は骨基質で最も豊富に 発現する成長因子の一つであるとともに，骨形成や脂肪 細胞への分化を促す。ラットと七トのin vivo の実験で は, IGF II は骨形成を促進し,さらに IGF I と IGF II は ラットの春椎からの細胞を骨芽前駆細胞と脂肪前駆細胞 に分化促進することが明らかにされている9”。一方, 本実 験では IGF II の活性を抑制すると考えられている Insulin-like growth factor binding protein 3 (IGFBP 3) は,すべてのドナーで発現が減少していた（3日目 0.36 fold, 7 日目 0.39 fold, 14 日目 0.19 fold)。IGF 結合夕 ンパクは, 血流中のIGF を運搬するキャリアーとなった り, 細胞外基質に貯蔵したりする役割をもち, IGFが IGFレセプターに結合するのを妨げることで IGF の活 性を抑制する。ただし，IGFBP 3 と IGFBP 5 は IGF あ るいはIGFレセプターに依存しない機序で骨芽細胞へ の IGF 刺激を増強するなど, 細胞機能を調節する働きを もつ可能性が示唆されている ${ }^{10)} 。$ 本実験でみられたIGF II 発現の増加は, IGFBP-3 発現の減少による抑制の解 除によるものであると考元られる゙，その機序には，両 者の結合が関与するものとしないものが考岳られる。 IGF IIの発現が，7日目をピークにしてすべてのタイム ポイントで増加していたことから, IGF II は骨芽細胞へ の分化に対して, その早い段階から後期にいたるまで重 要な機能を果たしていると考えられる。

また，骨量を調節する重要な役割をもつレセプター, LEPR は 3 日目で 3.2 fold, 7 日目で 5.2 fold, 14 日目 2.2 fold であった。Leptin は骨形成において重要な役割 を果たすこと战が知られ，Leptinと Leptin receptor ノックアウトマウスでは, 骨芽細胞のシグナル伝達が起 こらない ${ }^{12)}$ 。さらに Leptin は, OPG および骨芽細胞依存 的に破骨細胞の分化を阻害することも知られている ${ }^{13)}$ 。 Bassilana ら ${ }^{14)}$ の報告と同様, 本実験により, hMSC が骨 芽細胞に分化する過程でLEPR の mRNA 発現レベル が上昇することが確認された。このことは，骨芽細胞へ の分化が起こる環境においては, 骨量調節因子も関与し, 破骨細胞の分化阻害による骨形成優位の状況となること を示している。

成長因子レセプターの一つである, Fibroblast growth factor (FGF) のレセプター, FGFR 2, FGFR 3 も 7 日 目で強い発現が認められた。FGF は, 軟骨形成と骨形成 の両方で重要な役割をもち, FGFR からのシグナルは細 胞数の増加, 増殖停止, 分化を引き起こすす5)。FGFR 2 は 骨芽細胞前駆幹細胞の増殖期にのみ発現し, FGF 2 レベ ルの増加により FGFR 2 発現と増殖が抑制される ${ }^{16) 。 ~}$ FGFR 3 は, 軟骨細胞の増殖に必須であるとともに, 骨成




系幹細胞における軟骨細胞分化過程で, BMP-2 によっ てその発現上昇が上昇する ${ }^{18)}$ 。

以上のように，本実験においては 7 日目に，これら細 胞増殖に関与する成長因子が大きな変動をみせており,

細胞増殖が活発だったことが推測される。

一方, 分化誘導後 7 日目から 14 日目にかけては多くの 遺伝子発現が誘導され，特に転写因子が多くみられた。

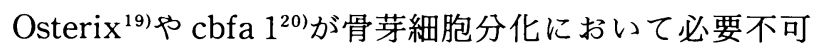
欠な転写因子として知られるように，骨芽細胞分化の過 程ではさまざまな転写因子が機能している。特に 14 日目 で, ROR $\alpha$ が 5.6 fold と強く発現上昇していたのは興味 深い結果である。ROR $\alpha$ は, あらゆる組織に広く発現し ており，核内レセプタースーパーファミリーに属する転 写因子で, 最近ラット骨肉腫由来の細胞株 ROS 172.8 に おいて BSPを活性化することが報告されている。

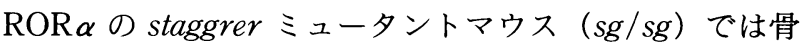
密度が著しく減少した骨減少症が認められ, 薄く長い骨 の形成が観察されるなど，骨代謝におけるその重要性が 確認されている211。本実験においても，BSP の発現上昇 に先立って, 緩やかに ROR $\alpha$ の発現が上昇しており, 骨 芽細胞への分化後期に機能するものと考えられる。

\section{V. 結 論}

本稿では，3 名のドナーから採取した hMSC の骨芽細 胞分化過程にみられる遺伝子発現の変動を示した。骨芽 細胞誘導後の 14 日間は, 主に細胞増殖と骨基質成熟の時 期であると考えられ, 骨芽細胞への分化過程の初期から 中期に相当するものと考えられる。本実験では, IGF II, LEPR, FGFR 3, ROR $\alpha$ などの mRNA レベルの変動が 顕著に認められ，これらの遺伝子の骨芽細胞分化初期か ら中期への関与とその重要性が示唆された。

\section{Acknowledgements}

This research was supported by Professor Lyndon F. Cooper. I would like to express our appreciation to him for his invaluable advice. I thank Professor Hiroyuki Miura and Professor Katsumi Uoshima for their suggestions. I also thank the members in Bone Biology and Implant Therapy Laboratory at the University of North Carolina at Chapel Hill, and Dr. Hideya Hamano, and the members in Fixed Prosthodontics, Department of Restorative Sciences, Division of Oral Health Sciences, Graduate School, Tokyo Medical and Dental University.

This study was presented at 81 st General session of the IADR (June 26, 2003, Goteborg).

\section{文献}

1) Jia, L., Young, M. F., Powell, J., Yang, L., Ho, N. C., Hotchkiss, R., Robey, P. G. and Francomano C. A. : Gene expression profile of human bone marrow stromal cells: high-throughput expressed sequence tag sequencing analysis. Genomics 79:7-17, 2002.

2) Sekiya, I., Vuoristo, J. T., Larson, B. L. and Prockop, D. J. : In vitro cartilage formation by human adult stem cells from bone marrow stroma defines the sequence of cellular and molecular events during chondrogenesis. Proc. Natl. Acad. Sci. USA 9 : 43974402, 2002.

3) Doi, M., Nagano, A. and Nakamura, Y.: Genomewide screening by cDNA microarray of genes associated with matrix mineralization by human mesenchymal stem cells in vitro. Biochem. Biophys. Res. Commun. $290: 381-390,2002$.

4) Haynesworth, S. E., Goshima, J., Goldberg, V. M. and Caplan, A. I. : Characterization of cells with osteogenic potential from human marrow. Bone 13 : 81-88, 1992.

5) Jaiswal, N., Haynesworth, S. E., Caplan, A. I. and Bruder, S. P. : Osteogenic differentiation of purified, culture-expanded human mesenchymal stem cells in vitro. J. Cell. Biochem. 64 : 295-312, 1997.

6) Cooper, L. F., Harris, C. T., Bruder, S. P., Kowalski, R. and Kadiyala, S. : Incipient analysis of mesenchymal stem-cell-derived osteogenesis. J. Dent. Res. $80: 314^{-}$ $320,2001$.

7) Diefenderfer, D. L., Osyczka, A. M., Reilly, G. C. and Leboy, P. S. : BMP responsiveness in human mesencymal stem cells. Connect. Tissue Res. $2003: 305-311$, 2003.

8) Linkhart, T. A., Mohan, S. and Baylink, D. J. : Growth factors for bone growth and repair: IGF, TGF beta and BMP. Bone 19(Review) : 1 S-12 S, 1996.

9) Jia, D. and Heersche, J. N. M. : Insulin-like growth factor-1 and -2 stimulate osteoprogenitor proliferation and differentiation and adipocyte formation in cell population derived from adult rat bone, Bone 27 : 785-794, 2000.

10) Rosen, C. J., Donahue, L. R. and Hunter, S. J. : Insulinlike growth factors and bone: the osteoporosis connection. Proc. Soc. Exp. Biol. Med. 206(Review) : 83102, 1994.

11) Takeda, S. and Karsenty, G. : Central control of bone formation. J. Bone Miner. Metab. 19(3) (Review) : 195-198, 2001.

12) Ducy, P., Amling, M., Takeda, S., Priemel, M., Schilling, A. F., Beil, F. T., Shen, J., Vinson, C., Rueger, J. M. and Karsenty, G. : Leptin inhibits bone formation through a hypothalamic relay: a central control of bone mass. Cell $100: 197-207,2000$.

13) Holloway, W. R., Collier, F. M., Aitken, C. J., Myers, D. E., Hodge, J. M., Malakellis, M., Gough, T. J., Collier, G. R. and Nicholson, G. C. : Leptin inhibits osteoclast generation. J. Bone Miner. Res. 17:200-209, 2002.

14) Bassilana, F. and Susa, M. : Human mesenchymal stem cell undergoing osteohenic differentiation express leptin and functional receptor. J. Bone Miner. 
Res. 15 : S 378, 2000.

15) Goldfarb, M. : Functions of fibroblast growth factors in vertebrate development. Cytokine Growth Factor Rev. $7: 311-325,1996$.

16) Iseki, S., Wilkie, A. O. M., Heath, J. K., Ishimaru, T., Eto, K. and Morriss-Kay, G. M. : Fgfr2 and osteopontin domains in the developing skull vault are mutually exclusive and can be altered by locally applied FGF 2. Development 124 : 3375-3384, 1997.

17) Deng, C., Wynshaw-Boris, A., Zhou, F., Kuo, A. and Leder, P. : Fibroblast growth factor receptor 3 is a negative regulator of bone growth. Cell $84: 911-921$, 1996.

18) Hoffmann, A., Czichos, S., Kaps, C., Gazit, D., et al. : The T-box transcription factor Brachyury mediates cartilage development in mesenchymal stem cell line C3H10T1/2. J. Cell Sci. 115(4) : 769-781, 2002.

19) Nakashima, K., Zhou, X., Kunkel, G., Zhang, Z., Deng, J. M., Behringer, R. R. and de Crombrugghe, B. : The novel zinc finger-containing transcription factor osterix is required for osteoblast differentiation and bone formation. Cell 108:17-29, 2002.

20) Karsenty, G. : Role of Cbfa1 in osteoblast differentiation and function. Semin. Cell Dev. Biol. 11 (Review) : 343-346, 2000.

21) Meyer, T., Kneissel, M., Mariani, J. and Fournier, B. : In vitro and in vivo evidence for orphan nuclear receptor RORalpha function in bone metabolism. Proc. Natl. Acad. Sci. USA 97 : 9197-9202, 2000.

22) Thomas, T., Gori, F., Khosla, S., Jensen, M., Burguera, B. and Riggs, L. : Leptin acts on human marrow stromal cells to enhance differentiation to osteoblasts and to inhibit differentiation to adipocytes. Endocrinology 140(4): 1630-1638, 1999.

23) Rousseau, F., el Ghouzzi, V., Delezoide, A. L., LegeaiMallet, L., Le Merrer, M., Munnich, A. and Bonaventure, J. : Missense FGFR 3 mutations create cysteine residues in thanatophoric dwarfism type I (TD 1). Hum. Mol. Genet. 5(4) : 509-512, 1996. 